\title{
ate Formal Learning About the Past WAE in Schools in England
}

Mike Corbishley, University College London Institute of Archaeology, London, UK E-mail: m.corbishley@ucl.ac.uk

Sarah Dhanjal, University College London Institute of Archaeology, London, UK

\section{ABSTRACT}

This paper explains how archaeology has been used to teach history to children in English schools, museums and heritage sites. We describe six successful schools-linked projects then focuses on the Young Archaeologists' Club, which has over the past 40 years nurtured many members of today's archaeology professionals. Finally, we consider how archaeology education practitioners can use what has been learnt in those projects to plan for a sustainable future.

Résumé: Cet article explique comment en Angleterre l'archéologie sert à enseigner l'histoire dans les écoles, les musées et les sites du patrimoine. II décrit six projets, puis se concentre sur le Club des Jeunes Archéologues, qui depuis quarante ans a formé des élèves qui exercent maintenant la profession d'archéologue. La conclusion tire de ces projets quelques leçons pour l'avenir.

Resumen: Este artículo explica cómo en Inglaterra la arqueología se usa para enseñar historia en escuelas, museos y sitios del patrimonio. Describe seis proyectos y luego se enfoca en el Young Archaeologists Club, que durante cuarenta años ha capacitado a estudiantes que ahora practican arqueología. La conclusión extrae de estos proyectos algunas lecciones para el futuro.

\section{KEY WORDS}

Archaeology, Education, School curriculum, Informal learning, Evidence, Excavation, Objects 


\section{Introduction}

One of the most significant indicators of the place of archaeology in education is the position it is assigned by the government in the school curriculum. Archaeology has become an accepted part of studying history in English schools since 1988 with the introduction of a National Curriculum. Museums, art galleries and archives responded quickly to the new opportunities and started by addressing the needs of families and pre-school children. The Museum of London's Our Londinium project, for example, enabled young people to co-curate displays with objects, films and poems they created (Museum of London 2017). The museum worked with organisations such as an adolescent mental health unit, a young offenders' unit and a group working with unemployed young people. Between 2012 and 2015 over 150 young people, aged 16-21, took part in this project.

\section{Background}

In 1972 the Schools History Project was created to provide courses for schools with textbooks and packs of source material for use in English classrooms. The project "challenged the view of history as a 'received subject' which had dominated since 1900. Pupils were 'to do' history, not merely to receive it" (Sylvester, 1994: 16). Archaeological and heritage organisations, such as the Council for British Archaeology and English Heritage followed with their own programs, projects and resources (Corbishley 2011: 83-94).

\section{The National Curriculum of 1988}

The stimulus for using primary source material in schools was the introduction of a statutory National Curriculum with the passing of the Education Reform Act of 1988. However, there was some delay in publication because of controversy over the recommendations of the working groups; history was the most controversial and the statutory Order for History was only published in 1991. This long process saw fierce criticism, bullying and interference by politicians, pressure groups and the press (Graham and Tytler 1993; Corbishley 1999, 2011, Cannadine et al. 2011). There was also criticism from teachers. All of this brought about revisions in 1994, 1999, 2007 and 2013 which largely meant "slimming down".

Despite the controversies, the National Curriculum brought about many changes in the way in which teachers, in both primary and secondary schools, set about providing opportunities for their pupils for "doing" his- 
tory in school, in the museum, and at monuments and historic buildings. The 1999 history curriculum had two sections. The first, called "Knowledge, skills and understanding", had five areas specifying what had to be taught at each stage in school:

1. "Chronological understanding"- that is, putting events, people, places in periods, using dates and correct terminology;

2. "Knowledge and understanding of events, people and changes in the past"-that is, features of different periods and societies, changes over time;

3. "Historical interpretation"-that is, recognising the different ways the past has been and is being interpreted;

4. "Historical enquiry"- that is, using a range of sources to enquire about the past, asking questions, selecting and recording information, including using objects and visits outside the classroom;

5. "Organisation and communication"- that is, organising historical information, using historical vocabulary and communicating in a variety of ways.

The second part, called "Breadth of study", specified which periods of history should be studied, covering British history, both local and national, from the coming of the Romans to the twentieth century. There were also some requirements to study European and World cultures (DfEE/QCA 1999, 2004).

\section{The New National Curriculum of 2013}

The loudest and longest protests about the National Curriculum came from serving school teachers who felt overburdened by paperwork, testing pupils, and the imposition of government regulations, which got in the way of what the curriculum was supposed to be about-pupils being given the opportunity to learn about subjects rather than teachers just teaching them. Archaeologists, and museum and heritage educators felt that the frequent revisions from 1999 to 2007 simply watered down the evidencebased learning about the past. They deeply resented the fact that the prehistory of Britain was not included in England's original National Curriculum History, while it remained an important part of history curricula elsewhere in the United Kingdom (in Wales, Scotland, and Northern Ireland). In 2013 the curriculum was revised again and it now begins at primary level with prehistoric Britain and finishes with the post-World War II period for secondary schools (DfE 2013). Local history and world history 
elements are mandatory at all levels, which gives archaeologists a great opportunity to contribute.

\section{Archaeologists as Educators}

Britain has a long history of discovery and involvement in the practice of archaeology, landscape surveying, discovery of ancient monuments, collection of artifacts, and scientifically controlled excavation. Visiting ancient monuments and museums is still a popular pastime and many visitors are parents bringing their children on the schools' half-term break, often to support their children's learning (Prior et al. 2015: 19). They can usually take part in free activities for children, including object handling, role play, creating art and story-telling.

People in the UK, especially in or near urban centres, have the chance to see archaeologists at work when they arrange open days on their sites. These open days are invariably popular and usually attain high visitor figures. But the most frequent request from schools, and some families, is for their young people to take part in "real archaeology", which invariably means digging. As archaeologists and educators, we know the educational value of working on a site. Such projects can facilitate practical understanding of a wide range of subject including maths, art, history and geography, as well as supporting the outdoor learning agenda (Corbishley 2011: 149-190, 217-235). It is only when teachers observe this in action that they appreciate how "rich" an educational experience it can be, as the following example proved.

\section{A Real Excavation in School Grounds}

The Institute of Archaeology of University College, London (UCL), along with Hendon and District Archaeological Society (HADAS), engaged in excavations at Hendon School, a secondary school in North London, between 2006 and 2012 (Moshenska et al. 2011; Dhanjal et al. 2015). The school approached the archaeologists with an interest in engaging young people in Local Authority care with the process of archaeology. The project quickly developed into an extracurricular offering for both the students in care and for those from the Gifted and Talented cohort at Hendon (the top $10 \%$ of the school). The aims of the project were: to enable students to use archaeology and history to explore their local area, in particular the local historical claim that John Norden, a cartographer in the time of Elizabeth I, had lived on the site; to enable the young people to engage with HADAS members and UCL students-giving UCL students a chance to 
gain experience in education work; and to further the aims of UCL Institute of Archaeology in Widening Participation.

Widening Participation was a Labour Government initiative to encourage $50 \%$ of 18 to 30 year olds into Higher or Further Education by 2010, particularly from under-represented backgrounds including: Black and Minority Ethnic groups; families with no history of further education; and people with disabilities. The program has since morphed into a Conservative program to encourage outreach by universities charging the highest fees, with similar aims. The project engaged with over 400 students over the 6 years it was running. Being within a Greater London Borough, Hendon School has a highly diverse student body, but the possibility of engagement with archaeology within their own school grounds gave the students a sense of ownership.

We experimented with teaching methods during the first 3 years, after which we created a handbook of resources for both archaeologists and pupils that has since been used here and in other projects. But when the school asked us to work with the whole of the first year, we found that the quality of our interactions suffered as did both our engagement and that of many of the students. We demonstrated to the school that our activities worked best in smaller groups. In that setting our main aim was to show that archaeology is "more than just digging", enabling the students to work on map research, surveying, geophysical survey and post excavation

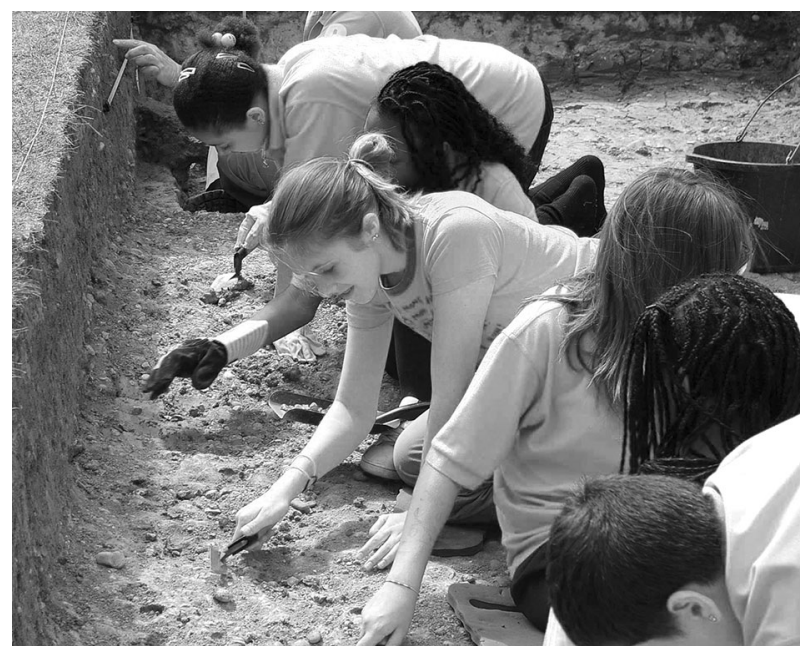

Figure 1. Pupils at Hendon School on site. During the project they also took part in finds processing, surveying, geophysical survey and interpretation of the site. These activities all allowed the pupils to experience real life applications of their learning in the classroom. Courtesy of Sarah Dhanjal 
work (Figure 1). Archaeologically, the project exceeded our expectations. As well as proving the John Norden hypothesis wrong, we were also able to extend the period of archaeological interest, finding substantial amounts of Saxon pottery. The students made tangible contributions to both of these results. One of the cohort went on to study archaeology at UCL and many more were inspired to aim higher in terms of university education, while the UCL students gained hands-on experience. The community archaeology phenomenon in the UK has now been documented in great detail (for example, Richardson 2014; Simpson 2010; Thomas 2010).

\section{Simulated Digs with Schools and Children}

To satisfy the requests for participating in "real" excavations, archaeologists in museums and other organisations have either set up small excavations or created simulated digs and these activities have become more popular in recent years. "Dig box" is the generic term for what are often called simulated dig sites, excavation activity, shoebox, or fish tank digs. These can be full-size excavation areas but are usually much smaller places. Whilst many dig boxes have been little more than a "lucky dip" for finds, the model created by the Museum of London (MoL) emphasised the concept of archaeological stratigraphy. In 2001 the MoL held a temporary summer activity called "The Dig," in which families and schools were introduced to the concept of archaeology by working archaeologists. After a short briefing, they excavated real objects in boxes simulating archaeological features from known sites in London. Buried in sand within the boxes were genuine unstratified artifacts, which the young people excavated, recorded and compared with whole pieces to date them. They then shared their discoveries with other participants. The Canterbury Archaeological Trust (CAT) made similar boxes for family activities at their "Big Dig" in the centre of the city (Figure 2).

At a small museum at Dunwich in Suffolk, two dig boxes were set in the ground outside the museum building. They had archaeological features that replicated those found on real excavations in medieval Dunwich, including pits, postholes, and a stone wall; finds were those recovered in excavations, mostly pottery sherds (Figure 3 ). Besides digging the covering layers and recording the features, the children had sessions on handling and identifying these and other objects from the museum's collections. On a smaller scale, the Young Archaeologists' Club branch in the UCL Institute of Archaeology built archaeological sites in fish tanks and then took part in their excavation (Figure 4). After each layer was created its features were recorded and photographed. Other Young Archaeologists later excavated the layers and compared their interpretations to the original pho- 


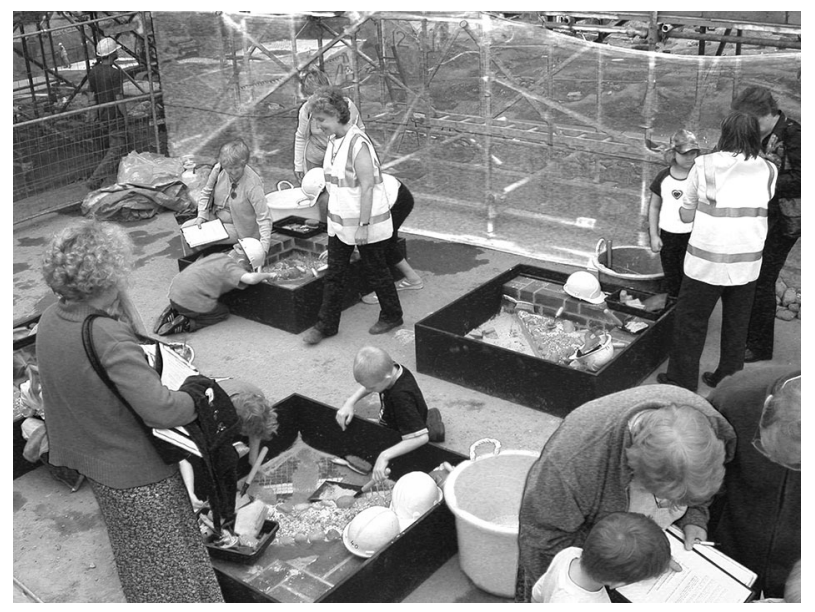

Figure 2. Dig boxes at the 'Big Dig' site in Canterbury in a visitor centre and viewing platform for the public and school groups. A number of other activities were carried out by the Canterbury Archaeological Trust including tours and object handling and identification. Courtesy of the Canterbury Archaeological Trust

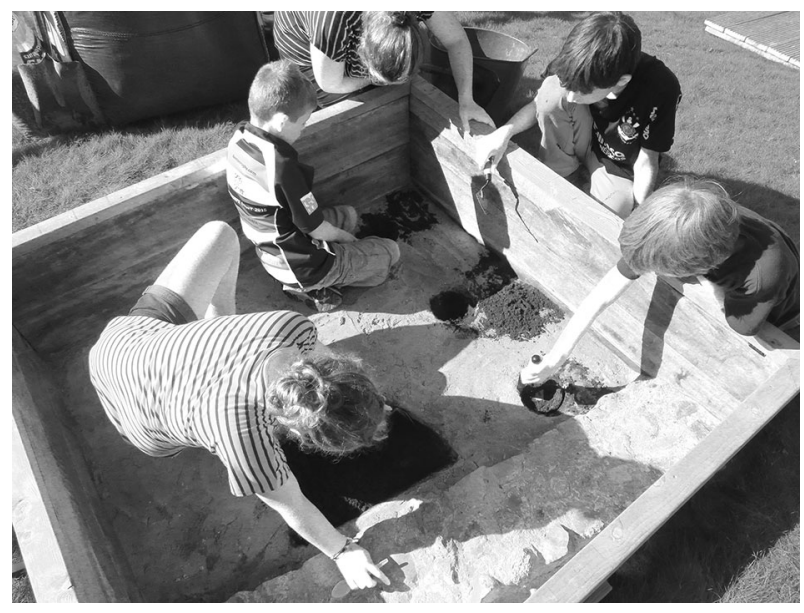

Figure 3. One of the dig boxes at Dunwich museum. A family group are excavating features which have been replicated from the records of an excavation of part of the medieval abbey in the town. Courtesy of Mike Corbishley

tographs and 'site' drawings. This was effective in terms of their understanding that archaeologists can only interpret what actually remains on site. 


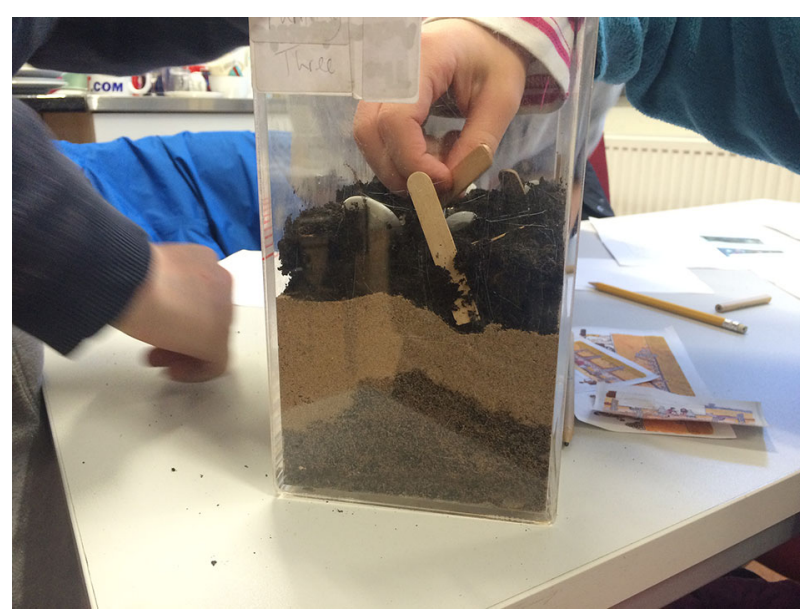

Figure 4. Members of UCL YAC constructing archaeological sites in 'fish tanks'. The construction stage of the activity helps the members understand taphonomic processes. The members swap 'fish tanks' for the excavation stage, which allows them to compare their interpretations with the stories told by the constructors of the site. Courtesy of Sarah Dhanjal

\section{Looking at Objects}

Object handling, from any period or culture, is useful in developing skills such as observing and examining, knowledge such as how people viewed their world, and concepts such as chronology (Durbin et al. 1996: 5) and objects are now regularly used by schools to teach history; for instance, pupils are asked to bring in objects from home when they are studying modern periods. Teacher trainers, especially in Continuing Professional Training courses, continue to reinforce the effective use of objects and visits to museums, historic sites and excavations. Many museums and heritage places will arrange object handling for school groups in term time and for family groups in the school or national holidays and there are useful guides for teachers on the use of objects (Corbishley 2011: 236-250).

\section{The Garbology Project}

This project, inspired by the Garbage Project in Arizona, began in 2005 as a joint project between the Archaeological Service and the Waste Management Service of the Suffolk County Council. The project was aimed at schools, families, youth groups, home educators and communities to raise awareness of their local heritage through the archaeology of past domestic rubbish and to develop it as a cross-curricular learning resource within the 
National Curriculum, such as speaking and writing in English and as part of social studies (Figure 5). All the groups handled and investigated objects, and youth and community groups carried out experimental archaeology, building clay ovens and Iron-Age houses. Both the archaeology and the waste management parts of the Garbology Project formed the basis for involvement with visual and dance artists. Schools held their own exhibitions of photographs, paintings and digitally manipulated images. A dance without words was performed in a regional theatre which presented the five stages of waste: Discarded (objects thrown away), Found (fragments washed and identified), Reconnected (putting fragments together to form recognisable everyday objects), Memories (students questioning older people about more recent finds) and Waste (students dressed as organic and inorganic material with a finale holding the placards RECYCLE, REUSE, REDUCE) (Allan 2008; Corbishley 2011: 304-311; Sustainable Aggregates 2008).

\section{Linking with the School Curriculum: The Canterbury Archaeological Trust}

The Canterbury Archaeological Trust (CAT) was created in 1972 as part of a general trend in Britain to deal with the implications of large-scale modern redevelopment of our complex archaeological heritage. Professional archaeologists formed units, often at the instigation of joint committees of

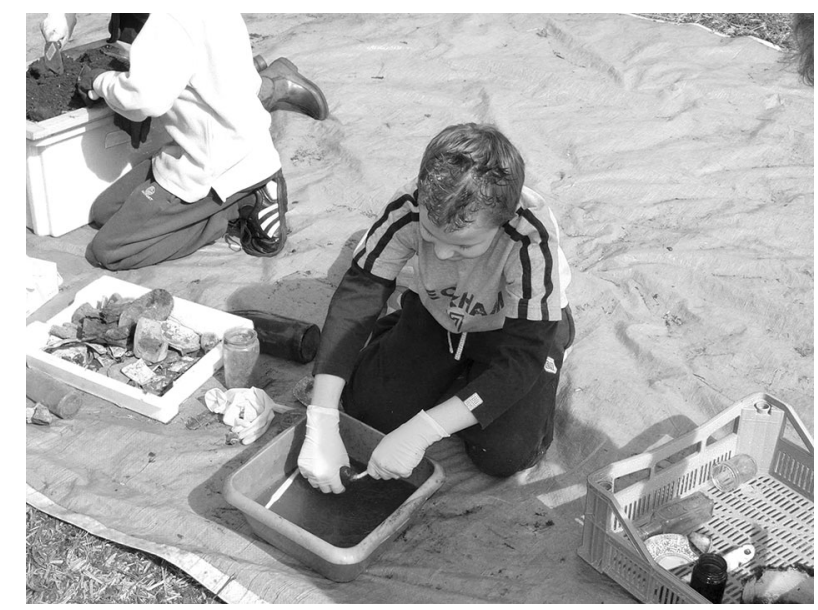

Figure 5. Garbology Project. A school group is cleaning objects from the excavation of a Victorian rubbish pit close by. The group then discusses with an archaeologist the objects, their possible use and where they might have come from. Courtesy of Mike Corbishley 
representatives from museums, universities, local authorities, and local and regional archaeological societies. Canterbury's problems were like those of many early cities where deeply stratified archaeological remains were going to be dug away, often for shopping precincts with deep underground access. Professional archaeologists wanted to draw the public's attention to the destruction of the historic environment and to explain what archaeological investigation could achieve.

Part of this strategy was to develop specific programs for schools. The CAT's policy is "to support the implementation of the new National Curriculum" and its general founding statement committed it to "promote the advancement of public education in the field of archaeology" (CAT 2017). It employs an Education Officer who provides a range of resources for teachers to use in the classroom, activities on sites under investigation by the Trust's archaeologists, talks and loan boxes for schools. The education service also provides learning activities for further and higher education. In addition, CAT runs open days on sites under excavation, archaeology field schools and courses for the public and local archaeological groups. It has a range of outreach projects, volunteers and a Friends of the Trust group.

\section{Evaluation}

There has been little formal and systematised evaluation of the learning process in archaeological education activities such as the ones we have presented. Feedback in the form of a plenary or discussion allows the facilitator to gauge how well an activity has worked, but it is highly informal. The Heritage Lottery Fund has also had some effect on the process of evaluation of education programs, insofar as recipients of grants must evaluate their demographics, how well they met targets, whether the sessions, facilitators and levels of enjoyment are of a high enough standard, etc. This does not actually involve the targets of the learning, but instead elicits observations on changes in young people from teachers, parents and carers.

To improve on this, the former public body Museums, Libraries, Archives (MLA) created a framework, called Inspiring Learning for All (ILFA) which was to be used to structure activities and to evaluate their efficacy. Two sets of learning outcomes were formulated: the Generic Learning Outcomes (GLOs) includes knowledge and understanding; skills; behaviour and progression; enjoyment, inspiration and creativity; and attitudes and values, while the Generic Social Outcomes (GSOs) include health and wellbeing; strengthening public life; and stronger and safer communities. An organisation using the framework would use it to create their activity, decide on the evidence to collect to prove the effectiveness of the 
activity in those areas and then structure the evaluation of the evidence. The impact of ILFA has been most felt in museums, often in exhibition development rather than educational activities. It continues to be maintained by another public body, the Arts Council England (Arts Council England 2017).

\section{The Young Archaeologists' Club}

The Young Archaeologists' Club (YAC), initially called Young Rescue, was formed in 1972 by Kate Pretty, a professional archaeologist who realised that working on archaeological sites was becoming more inaccessible to young people as a result of the growing professionalization of archaeology. She suggested that it was important to "find ways in which young people could become interested and involved in archaeology without digging" (Pretty 1999: 88). Over the years, activities have included simulations of archaeology, archaeologically themed arts projects, and experimental archaeology, which are all popular topics. It remains the only national club for young people interested in archaeology in the UK.

The first branch was in Cambridge; a newsletter was produced by Mike Corbishley and holiday activities were run by Katherine Chant (Pretty 1999: 88). Branches began to be established around the UK and Young Rescue was renamed the Young Archaeologists' Club (YAC) in 1981, following a competition among the young members. The administration of the club moved first to the York Archaeological Trust in 1987 (Henry 2004: 90) and, since 1993, to the Council for British Archaeology (CBA). From the original club, two sides developed: YAC members received a regular magazine, offers, competitions and the opportunity to go on fieldwork weekends or week-long holidays, but did not all have access to branches. The branch network, which varies in size, now has around 70 branches, some overseas. Many branch members were not YAC members, which resulted in a split membership.

The network itself is administered centrally, the focus being an email list for leaders to keep in contact, share ideas and potentially work together. It does not extend to the members. Since the General Financial Crisis of 2008, times have been financially hard. Much of the cost of running the YAC has been in administration, both for the volunteers running the branches (processing applications and obtaining references; regular police checks; maintaining contact with the network via email; arranging branch insurance) and for publishing the magazine. In 2014 YAC decided to concentrate on the branch network by disbanding the YAC membership and magazine, instead providing information, articles and activities on a new website, www.yac-uk.org (YAC 2017). 
The branches are mostly run by volunteers, with some run by education officers as part of their programs. Some volunteers are working archaeologists, some are interested parents, others have an archaeological background and volunteer at YAC to keep in contact with the profession; in applying, they must indicate their relevant experience and interests, have a criminal records check and be vetted by a panel. The club is for 8 to 16 year olds; at the age of 17 , members can become leaders, helping to run sessions or even creating sessions themselves. Branches have their own policies on whether parents may also attend sessions, often asking that they become leaders in accordance with child protection policies.

The creators accepted from the start that the branches would be run independently by different people and therefore their activities would vary. The clubs are also limited by their locations: some are based in museums, universities or archaeological units while others have no regular meeting place and have to hire local community halls or spaces or meet outside, weather permitting. These two issues pose a wide range of challenges. The archaeological knowledge of leaders varies due to their diverse backgrounds. Those with specialized archaeological knowledge and contacts may tailor their activities accordingly, whereas other leaders may take a more generalist approach. The location of branches also affects what they are able to do: urban branches often have a more diverse membership, but have less access to sites and landscapes; rural sites are challenged by the distance members need to travel to attend, but often have rich archaeological resources in their local area.

Today around 1600 young people are involved in YAC branches and members tend to be more ethnically diverse than the leaders. YAC welcomes a membership with a wide range of learning difficulties and disabilities-anecdotal evidence from branch leaders suggests that is because it offers interactive learning and informal fun activities. This may also be why YAC attracts families of home-educators. It is hard to say what happens to members once they leave, as data protection means we cannot keep contact details. The split between former club membership and branch membership also makes it difficult to know how many people have been YAC members. To counter this, YAC recently set up an alumni group on Facebook to keep in touch with former members, garner their support and demonstrate the effectiveness of YAC long-term. It currently has around 200 members.

Running a YAC branch differs from normal archaeology and education programming. YAC branches tend to have a core membership, which comes to meetings regularly over an extended period of time. The rest of the membership attends on a meeting-by-meeting basis. Members can attend for many years, therefore activities are often run only once. YAC is necessarily quite labour-intensive, each monthly meeting and the activities 
within it requiring planning, risk assessment and booking administration. Sessions tend to run on low or minimal resources. However, the great benefit is that sustained contact with our members means that we can provide continuity, sometimes through to university level. Young people have input into the programme, choosing or suggesting topics.

\section{University College London YAC}

The authors run the University College London YAC, which had its first meeting in 2005. It was set up with funding from the Heritage Lottery Fund (HLF), which the Local Authority in Camden, a Borough of London, had obtained, as part of their Camden Young Archaeologists' project. The Club was seen as a legacy of the 3-year project, which engaged with schools and young people in summer school programs. UCL Institute of Archaeology was a partner in the project and an obvious host. Our leaders were and still are drawn from UCL staff and students and alumni. In addition, archaeologically-trained people regularly contact us as potential volunteers.

The Club was initially restricted by the Local Authority to working with young people in the Camden area. Because of the HLF funding, evaluation focused on collecting demographic data such as age, gender and ethnicity and levels of enjoyment of the activities, so we know that the branch had at least 50\% membership from Black and Minority Ethnic groups, reflecting Camden borough (Corbishley 2011, 339). That funding ended after 2 years and the club was able to branch out. In just over 10 years there have been 112 sessions, ranging from 2 hours to whole days (London Camden YAC 2017). The sessions have had 1504 attendances from 147 different members.

Membership still reflects London's diverse nature, as does the branch leadership. We offer a friendly and welcoming atmosphere and explore archaeology in an interactive way, inspired strongly by Science Communication methods. Our location is enviable. Within UCL, we have access to museums, objects and specialist expertise. We are also able to travel around London to visit museums and sites (Figure 6). However, we have relatively little access to large areas of outside space, archaeological landscapes or excavations.

\section{Challenges}

There are numerous challenges entailed in running a YAC. One is the 8-16 age range, which in terms of formal education straddles primary and secondary. At the younger end of the membership, interests change rapidly, but the older cohort tend to focus their sights on university as they study 


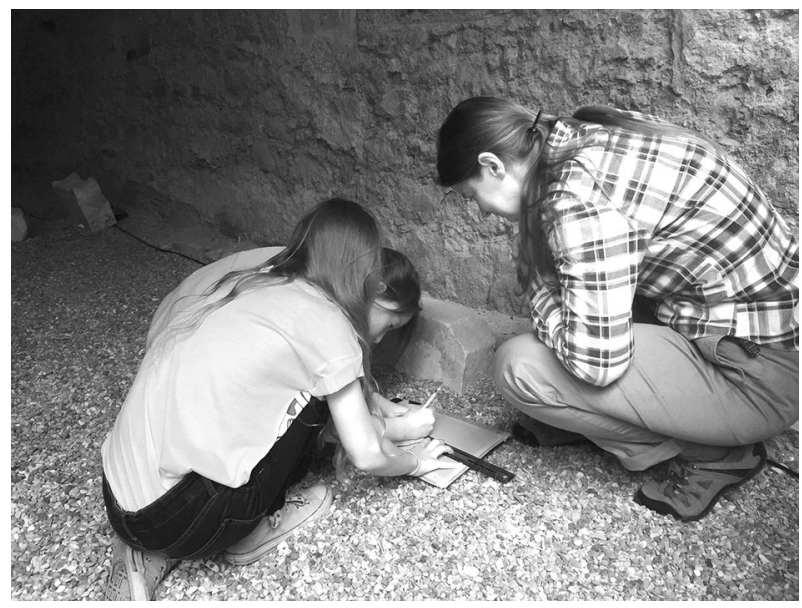

Figure 6. Members of YAC working on site drawings in the Charnel House in Spitalfields, London. Site visits and non-invasive archaeological activities form a large part of YAC branch activities. Courtesy of Gideon Feldman

for their public examinations: General Certificate of Secondary Education (GCSE) at 16, of which only English, Maths and Science are compulsory and good levels tend to be required in most jobs and any kind of further education; Advanced-Levels (A-Level) at 18 are the main qualifications used to apply for university. This means that we have to provide sessions that are active but are naturally differentiated, so that older members can be challenged whilst younger members are still able to achieve and enjoy. We have previously run a series of workshops in conjunction with another London branch, aimed at stretching older members by studying a site represented in the Museum of London Archaeological Archive, with our members working on the material from a site in London to establish an interpretation, as was done at HADAS.

\section{The Future of Archaeology in Education}

By specifying the need to work with archaeological material, the National Curriculum has helped museums and heritage sites to create more focused activities for school groups, facilitating an understanding of both their own "unique selling points" and the needs of teachers. Museums and sites and some heritage conservation bodies have been instrumental in encouraging teachers physically to take learning outdoors (Council for Learning Outside the Classroom 2017; Forestry Scotland 2017). There is, however, a clear need for all archaeological organisations who do or want to do "educa- 
tion" activities to employ staff or volunteers who are experienced in the classroom and outdoor learning styles which do more than just "keep the kids occupied". School, family and adult groups enjoy being occupied at CAT sessions but they are also being educated.

Outside the classroom, extra-curricular offers have catered for the lifelong learning agenda, ensuring programming from toddlers to after school projects to adults, through museums, community archaeology, and even examples such as the HADAS course, aimed at people in the local area. Here archaeology educators have the opportunity to cater for the interests of their audiences and local needs rather than meet prescriptive curricula. This ability to be adaptable allows us to develop subject areas not covered by the National Curriculum, which are therefore often new to most audiences, such as elements of local history. We are thus able to champion the local historic environment, or projects that use common themes to unite diverse communities.

There is a huge variation in what is offered as archaeological education. We have observed that good and bad practice is often not shared. Practitioners often work in isolation and miss the chance to gain from others' experience and share their own innovations. But our view for the future is hopeful. As experienced practitioners we must ensure that our work is sustainable and devise ways of sharing with both teachers and archaeologists, in part through encouraging and supporting archaeologists with an interest in education. We train budding educators through YAC and universitylevel teaching, but would like to see even more sharing of good practice and bad practice where lessons can be learned. More detailed research about the pedagogical benefits of using archaeology in and outside of the classroom would be valuable. We need to improve the confidence of teachers and education authorities in using archaeology in their schemes of work. In-service teacher training is a vital method not only of training teachers to disseminate archaeology to their pupils but other teachers too. Finally, parents need better and more accessible information. Here the internet is a major resource, with many museums and sites providing great resources for schools. We would like to see similar sites specifically for families and home-schooled children.

\section{Open Access}

This article is distributed under the terms of the Creative Commons Attribution 4.0 International License (http://creativecommons.org/licenses/by/4. $0 /$ ), which permits unrestricted use, distribution, and reproduction in any medium, provided you give appropriate credit to the original author(s) 
and the source, provide a link to the Creative Commons license, and indicate if changes were made.

\section{References}

Allan, D.

(2008). Unlocking the potential: Exploring the Archaeology of Suffolk's aggregate landscapes, an outreach project for schools and communities. Suffolk County Council, Ipswich. http://archaeologydataservice.ac.uk/archiveDS/ archiveDownload?t=arch-1038-1/dissemination/pdf/project_report/ALSF_P roject_No_4838_Final_Report.pdf. Accessed 21 Dec 2017.

Arts Council England.

(2017). Inspiring learning for all. http://www.artscouncil.org.uk/advice-and-guida nce/inspiring-learning-all-home-page. Accessed 21 Dec 2017.

Cannadine, D., Keeting, J., \& Sheldon, N.

(2011). The right kind of history: Teaching the past in twentieth-century England. Basingstoke: Palgrave Macmillan.

CAT $=$ Canterbury Archaeological Trust.

(2017). Learning. Canterbury Archaeological Trust, Canterbury. http://www.canter burytrust.co.uk/learning/. Accessed 21 Dec 2017.

Corbishley, M.

(1999). The National Curriculum: help or hindrance to the introduction of archaeology in schools? In Communicating Archaeology (pp. 71-78). Occasional Paper No. 4 Bournemouth University School of Conservation Sciences. Oxbow Books, Bournemouth, Oxford.

(2011). Pinning down the past: Archaeology, heritage and education today. Woodbridge: The Boydell Press.

Council for Learning Outside the Classroom.

(2017). Home page. http://www.lotc.org.uk/. Accessed 21 Dec 2017.

DfE=Department for Education.

(2013). National curriculum in History: programmes of study. https://www.gov.uk/ government/publications/national-curriculum-in-england-history-progra mmes-of-study. Accessed 21 Dec 2017.

DfEE/QCA=Department for Education and Employment and Qualifications and Curriculum Authority.

(1999). The National Curriculum: Handbook for primary teachers in England. htt p://www.educationengland.org.uk/documents/pdfs/1999-nc-primary-han dbook.pdf. Accessed 21 Dec 2017. 
(2004 [1999]). The National Curriculum: Handbook for secondary teachers in England. http://webarchive.nationalarchives.gov.uk/20130401151715/, http://www.education.gov.uk/publications/eOrderingDownload/Q CA-04-1374.pdf. Accessed 21 Dec 2017.

Dhanjal, S., Flinn, A., Lockyear, K., \& Moshenska, G.

(2015). Dig where we stand: Community archaeology in action. In K. Lockyear (Ed.), The proceedings of archaeology in hertfordshire: A conference to mark the 80th birthday of Tony Rook (pp. 326-334). Hatfield: Hertfordshire University Press.

Durbin, G., Morris, S. \& Wilkinson, S.

(1996 [1990]). Learning from Objects. English Heritage, London

Forestry Scotland.

(2017). Outdoor archaeological learning: An outdoor learning resource for teachers. http://scotland.forestry.gov.uk/managing/work-on-scotlands-national-fore st-estate/conservation/archaeology/learning/outdoor-archaeological-learni ng. Accessed 21 Dec 2017.

Graham, D., \& Tytler, D.

(1993). A lesson for us all: The making of the national curriculum. London: Routledge.

Henry, Pippa.

(2004). The Young Archaeologists' Club: Its role within informal education. In D. Henson, P. Stone, \& M. Corbishley (Eds.), Education and the historic environment (pp. 88-92). London: Routledge.

London Camden Young Archaeologists' Club.

(2017). Home page. http://www.yac-uk.org/clubs/london-camden. Accessed 21 Dec 2017.

Moshenska, Gabriel, Dhanjal, Sarah, \& Cooper, Don.

(2011). Building sustainability in community archaeology: The Hendon School Archaeology Project. Archaeology International, 13, 94-100.

Museum of London.

(2017). Our Londinium project 2012. https://www.museumoflondon.org.uk/applic ation/files/5714/5468/0873/Museum-of-London-Accounts-2012.pdf. Accessed 21 Dec 2017.

Pretty, K.

(1999). Child's play: Archaeology out of school. In Communicating archaeology (pp 87-89). Occasional paper No. 4 Bournemouth University School of Conservation Sciences and Oxbow Books, Bournemouth, Oxford. 
Prior, G., Peter M. \& Angela C.

(2015). Taking part. Initial findings from the longitudinal survey. DCMS and TNS BMRB, London. https://www.gov.uk/government/uploads/system/upload s/attachment_data/file/447739/TP_longitudinal_report.pdf. Accessed 21 Dec 2017.

Richardson, L.

(2014). Public archaeology in a digital age. http://discovery.ucl.ac.uk/1436367/. Accessed 21 Dec 2017.

Simpson, F.

(2010). The values of community archaeology: A comparative assessment between the UK and the US. British archaeological reports international series. Oxford: Oxbow.

Sustainable Aggregates.

(2008). The sands of time: Aggregates extraction, heritage and the public. http://arc haeologydataservice.ac.uk/archives/view/alsfdisc_eh_2010/. Accessed 21 Dec 2017.

Sylvester, D.

(1994). Change and continuity in history teaching 1900-1993. In H. Bourdillon (Ed.), Teaching history (pp. 9-23). London: Routledge.

Thomas, S.

(2010). Community archaeology in the UK: Recent findings. http://new.archaeolog yuk.org/search-results?q=Thomas $\% 2$ C\%20Suzie $\% 202010 . \% 20 \% 20 \% 20 \mathrm{Co}$ mmunity\%20Archaeology\%20in\%20the\%20UK\%3A\%20Recent\%20Findi ngs.\%20. Accessed 21 Dec 2017.

YAC=Young Archaeologists' Club.

(2017). Home page. http://www.yac-uk.org/. Accessed 21 Dec 2017.

Publisher's Note Springer Nature remains neutral with regard to jurisdictional claims in published maps and institutional affiliations. 